\title{
Evaluation of Oral Microflora in Obese and Non- Obese Humans from District Faisalabad, Pakistan
}

\author{
Frisha Abkar ${ }^{1}$, Sajjad ur Rahman ${ }^{1}$, Ahsan Naveed ${ }^{1 *}$, Hira Rasheed ${ }^{1}$ and Syed Ashar Mehfooz ${ }^{2}$ \\ ${ }^{1}$ Institute of Microbiology, University of Agriculture Faisalabad, Pakistan \\ ${ }^{2}$ Department of Clinical Medicine and Surgery, University of Agriculture Faisalabad, Pakistan
}

Submission: January 09, 2019; Published: March 15, 2019

*Corresponding author: Ahsan Naveed, Institute of Microbiology, University of Agriculture Faisalabad, Pakistan

\begin{abstract}
Obesity is accumulation of excessive fat in an adipose tissue that leads to deleterious effects on the body. The oral microbiota may have a correlation with the obesity. Present study was performed to correlate oral microflora and obesity. A total of 100 saliva samples were collected, 50 from obese and 50 from non-obese individuals. The samples were processed according to the standard protocol for DNA extraction through GeneJet Genomic Purification Kit. The extracted DNA were proceeded to polymerase chain reaction (PCR) and sequencing. The bacterial species (Selenomonas noxia) was identified in $93 \%$ of the obese individuals at the level $>1.05 \%$ of the total salivary microbiota. Capnocytophage gingivalis was identified in $89 \%$ of obese median while Actinomyces gerenseriae and Treponema socranskii were present in $71 \%$ and $79 \%$ of the obese individuals respectively. Some of the bacterial species from all these phyla were recovered in both obese and non-obese individuals, however above-mentioned bacteria were only detected in obese. The overall research evidenced the presence of different oral microflora in healthy and obese individuals. These results support the correlation of oral microflora with the obesity.
\end{abstract}

Keywords: Obesity; Oral cavity; Microbiota; Actinimyces; Firmicuties; Bacteridties

\section{Background}

Digestive tract is place of residence for a lot more microbes. The oral microbes influence the individual's health, although there are other factors but the change in oral microflora is evidenced to lead the obesity. Present study was performed to develop a correlation between oral microflora and obesity.

\section{Introduction}

The condition in which abnormal or excessive amount of fat accumulate in adipose tissues called obesity. Obesity number was increased around the world in children and adults; it is most common in developed countries Bharmal et al. [1]. The normal and obese people differ from each other in two ways. The abnormal accumulation of fat in adipose tissues and second condition is the regional sharing of fat in the body. Due to obesity in the worldwide mortality and morbidity rates has been increased. Obesity is associated with psycho sociological disorders Burdette \& Hill [2]. Human microbiota comprises bacteria viruses arches the universal eukaryotes is more than $10^{14}$ microbial cells. According to research the Childs born by $\mathrm{C}$ section have great risk of obesity as compared to normal delivery. There is a link between early gut and later obesity bacterial colonization Blustein \& Liu [3].

The aim of study was to evaluate the oral microflora of obese and non-obese individual to check the role of microorganisms in the obesity. Obesity in worldwide can be controlled by evaluation of bacteria that was involved in the obesity.

Oral Bacteria + Food $\rightleftharpoons$ Gastrointestinal track, it may enhance the metabolic activity

Oral Bacteria $\longrightarrow$ it may increase the Appetite $\longrightarrow$ enhance the food consumption

Obesity is epidemic, excessive amount of fat causing the disturbance in the blood level of insulin access, bold fat, and sugar that may lead to diabetes, high blood pressure, and causing cardiovascular disorders due to fatty liver. Need to control obesity research focus the microorganisms that involved in obesity.

Numerous and different microorganisms are present in a human oral cavity it is revealed that a relationship between obesity and microbiota. On the intraoral surfaces complex microbial communities are made. Oral cavity of obese and lean people is different. A biological fluid is secreted from salivary glands called saliva Yamanaka et al. [4]. The saliva is containing microbiome from the communities of bacteria from many surfaces like intraoral surfaces. In the saliva the bacteria that are present are not blamed as an agent to cause oral disease Kaplan [5]. In the salivary microbiome indigenous bacteria is present. These bacteria varied from person to person Rasiah et al. [6]. The 


\section{Current Research in Diabetes \& Obesity Journal}

obesity is associated with the microbiota in saliva Goodson et al. [7]. For the diagnosis of disease and for health monitoring salivary microbiome was used as a surrogate indicator Yoshizawa et al. [8]

In the humans and mice Firmicutes and Bacrerioidetes are most abundant bacteria. The Bacterioidetes 20-40\% and Firmicutes $60-80 \%$ present in the humans and mice.

Ley et al. [9] mostly these bacterial representative phyla will not grow outside of the host. From surrounding ecosystem babies got their initial microbiota, especially the fecal microflora and maternal vaginal microflora Reinhardt et al. [8] among the family the human gut microbiome is shared Turnbaugh \& Elli et al. [11,12].

\section{Materials and Methods}

\section{Sample collection}

Saliva samples were collected from obese and non-obese individuals after prior permission of the individuals. The selected individuals were thoroughly examined for any disease/ abnormality, furthermore, the individuals were selected on the basis of their age and body mass index. All the selected individuals were non-smokers with minor to no habits of fast food intake. A total of 100 saliva samples were collected, 50 from obese individuals and 50 from non-obese. The individuals were selected in age limit between 25 to 60 years. The individuals were having a body mass index (BMI) of 27 to 32 .

\section{Saliva sample collection}

Unstimulated $3 \mathrm{ml}$ of saliva sample was collected in 100 sterile graduated cylinders. A $1 \mathrm{ml}$ of saliva sample was transferred into the Eppendorf tube with an addition of EDTA that was mixed by vortex and incubated at $52^{\circ} \mathrm{C}$ for 10 minutes.

\section{DNA extractions and quantification}

GeneJet Genomic DNA Purification Kit (Thermo scientific, Cat. \# K0721) was used for the extraction of DNA from saliva samples according to manufacturer's protocol. The purified DNA sample from saliva were quantified through Nano drop techniques and confirmed on 1\% Agarose Gel Electrophoresis (in 100ml TAE buffer $1 \mathrm{gm}$ agarose).

\section{Amplification of DNA through polymerase chain reaction (PCR)}

The DNA was processed through conventional PCR using two oligonucleotide primers the forward $27 \mathrm{f}$ and reverse $1492 \mathrm{R}$ of a bacterial 16S ribosomal RNA gene.

\section{F = 5'AGAGTTTGATCCTGGCTCAG 3'}

\section{R= 5'GGTACCTTGTTACGACTT 3'}

\section{Sequencing of $16 \mathrm{~s}$ rRNA}

The purified PCR product of samples were sent to Eurofins Genomics Company for sequence studies. Sequences were processed through NCBI Blast to identify bacteria and comparison of bacterial population in obese and non-obese population.

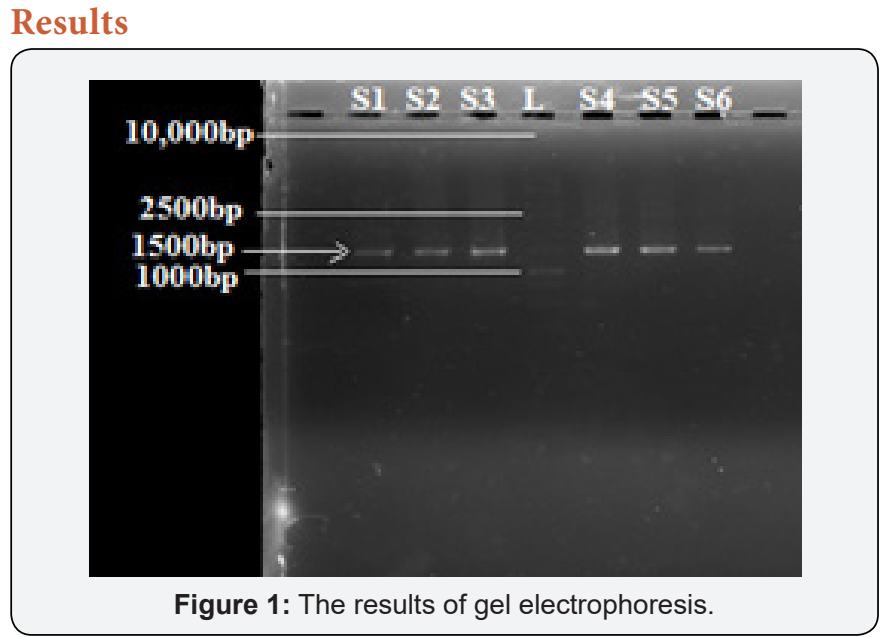

The DNA of obese and non-obese population was identified at $1500 \mathrm{bp}$. The results of gel electrophoresis are depicted in Figure 1. Lane S1-S3 presented obese population while S4-S6 is presenting non-obese population. The ladder of $1 \mathrm{~kb}$ is presented in lane $\mathrm{L}$.

The oral cavity of obese individuals showed presence of Tanerella forsythia, Capnocytophage gingivalis, and Capnocytophage sputigena from phylum bacteroides. While nonobese individuals were free of these bacteria. The Table 1 is presenting $\%$ age prevalence of different bacterial species from phylum bacteroides in the obese individuals. Tanerella forsythia was present in $83 \%$ of the obese median, Capnocytophage gingivalis was recovered from $89 \%$ while Capnocytophage sputigena $77 \%$ of the obese individuals. Some of the other bacterial species as Nesseria mucosa, Campylobacter rectus, Campylobacter gracilis, Campylobacter corrodens from phylum Bacteroides were recovered from both obese and non-obese individuals at different percentage as given in Table 1.

Table 1: Percentage prevalence of microbial species from the phylum Bacteroides in obese median

\begin{tabular}{|c|c|c|}
\hline Bacterial Species & $\begin{array}{c}\text { Percentage } \\
\text { Presence in Obese }\end{array}$ & $\begin{array}{c}\text { Percentage Presence } \\
\text { in Non-Obese }\end{array}$ \\
\hline Tanerella Forsythia & $83 \%$ & --- \\
\hline $\begin{array}{c}\text { Capnocytophage } \\
\text { Gingivalis }\end{array}$ & $89 \%$ & --- \\
\hline $\begin{array}{c}\text { Capnocytophage } \\
\text { Sputigena }\end{array}$ & $77 \%$ & -- \\
\hline Nesseria Mucosa & $47 \%$ & $53 \%$ \\
\hline Campylobacter Rectus & $31 \%$ & $36 \%$ \\
\hline Campylobacter Gracilis & $60 \%$ & $49 \%$ \\
\hline $\begin{array}{c}\text { Campylobacter } \\
\text { Corrodens }\end{array}$ & $51 \%$ & $54 \%$ \\
\hline
\end{tabular}

The bacterial specie Streptococcus intermedius was present in $87 \%$ of the obese individuals under study while Selenomonas noxia were detected in the $93 \%$ of the obese individuals. These fermicutes were absent in the oral cavity of healthy human population as presented in the Table 2 .

Streptococcus oralis, Streptococcus sanguis, Eubacterium nodatum, Eubacterium saburreum were found in saliva samples 


\section{Current Research in Diabetes \& Obesity Journal}

of both obese and non-obese individuals at varied percentage as shown in Table 2.

Table 2: Percentage prevalence of microbial species from the phylum Firmicutes in obese median

\begin{tabular}{|c|c|c|}
\hline Bacterial Species & $\begin{array}{c}\text { Percentage } \\
\text { Prevalence in } \\
\text { Obese Median }\end{array}$ & $\begin{array}{c}\text { Percentage } \\
\text { Prevalence } \\
\text { in Non-Obese } \\
\text { Median }\end{array}$ \\
\hline Streptococcus Intermedius & $87 \%$ & --- \\
\hline Selenomonas Noxia & $93 \%$ & --- \\
\hline Streptococcus Oralis & $61 \%$ & $57 \%$ \\
\hline Eubacterium Nodatum & $79 \%$ & $73 \%$ \\
\hline Eubacterium Saburreum & $54 \%$ & $63 \%$ \\
\hline Streptococcus Sanguis & $72 \%$ & $59 \%$ \\
\hline
\end{tabular}

Actinomyces israelii and Actinomyces gerenseriae were also detected in the oral microflora of the obese individuals under study. The oral microflora of the obese was containing Actinomyces israelii and Actinomyces gerenseriae in $71 \%$ and $63 \%$ as depicted in Table 3. Other notable bacterial species recovered from obese and non-obese individuals were Actinomyces odontolyticus, Propionibacterium, Actinobacterium acnes as given in the Table 3.

Table 3: Percentage prevalence of microbial species from the phylum Actinobacteria in obese median

\begin{tabular}{|c|c|c|}
\hline Bacterial Species & $\begin{array}{c}\text { Percentage } \\
\text { Prevalence in } \\
\text { Obese Median }\end{array}$ & $\begin{array}{c}\text { Percentage } \\
\text { Prevalence in Non- } \\
\text { Obese Median }\end{array}$ \\
\hline Actinomyces Gerenseriae & $71 \%$ & --- \\
\hline Actinomyces Israelii & $63 \%$ & --- \\
\hline Actinomyces Odontolyticus & $63 \%$ & $61 \%$ \\
\hline Propionibacterium & $47 \%$ & $45 \%$ \\
\hline Actinobacterium Acnes & $79 \%$ & $53 \%$ \\
\hline
\end{tabular}

Treponema socranskii was absent in the healthy individuals from the phylum Spirochaetae but these bacteria were present in the oral cavity of the $77 \%$ obese individuals as directed in the Table 4.

Table 4: Percentage prevalence of microbial species from the phylum Spirochaetae in obese median

\begin{tabular}{|c|c|c|}
\hline $\begin{array}{c}\text { Bacterial } \\
\text { species }\end{array}$ & $\begin{array}{c}\text { Percentage Prevalence } \\
\text { in Obese Median }\end{array}$ & $\begin{array}{c}\text { Percentage Prevalence } \\
\text { in Non-Obese Median }\end{array}$ \\
\hline $\begin{array}{c}\text { Treponema } \\
\text { Socranskii }\end{array}$ & $77 \%$ & --- \\
\hline
\end{tabular}

\section{Discussion}

The change in oral flora is directly related to obesity, the relationship of weight gains and changes of oral microflora is calculated in this research. The bacterial species were different in the saliva sample of overweighed individuals when compared with a bacterial species in normal individuals. Goodson et al. [7] Studied S.noxia was present in the obese individuals $2.56 \%$ and $0.00 \%$ from the non-obese individuals. While in resent study the results indicate the S.noxia was totally absent from the healthy individuals and present in $20 \%$ of obese individuals.
The bacterium S.noxia was capable of identifying $98 \%$ of obese individuals from healthy individuals. Illness competitor is S. noxia Selenomonads, it is known as gram negative Bactria, and it is motile, non-spore forming. The S.noxia participates in release of inflammatory mediators and inflammatory reaction triggering. S.noxia. It is intriguing to take note of that Selenomonas noxia was main Firmicutes which was fundamentally hoisted in the saliva. Different research has demonstrated that this inclination to put on weight in the mice is transmissible b/w mice by coprophagia. The creators guessed that the obese people have in the gut microbiota the more energy from the food is stored by the Fermicutes.

From Firmicutes phyla Streptococcus intermedius was absent from the non-obese individuals and present in the obese individuals, while according to the study of Goodson et al. [7] the presence of Streptococcus intermedius in the over weighted individuals was $0.63 \%$ and absent in non-obese individuals.

From phyla Actinobacteria the bacteria Actinomyces gerenseriae was present in the obese individuals, according to resent study and absent from the non-obese individuals. The research results of Goodson et al. [7] indicated the presence of Actinomyces gerenseriae in over weighed individuals was $2.28 \%$ while it was absent in healthy individuals. The other bacteria from Actinobacteria phyla the Actinomyces israelii was absent from the non-obese medium and present in the obese medium, while according to Goodson et al. [7], Actinomyces israelii was present in the obese individuals with $1.11 \%$ while absent in non-obese median.

Presently, the bacteria Treponema socranskii from phylum Spirochaetae was absent from non-obese individuals and present in the obese individuals the results are in accordance with Goodson et al. [7] where $1.14 \%$ obese individuals were having Treponema socranskii and it was no recovered from non-obese individual.

Investigation of populaces with periodontitis and without periodontitis showed that $70 \%$ periodontitis were stout compared to $37 \%$ normal people Socransky \& Haffajee [13]. Furthermore, obese people have serious periodontal illness, when assessed by the plaque, seeping on examining, take profundity, connection misfortune, and level of the sub gingival T. forsythia. TNF $\alpha$ is one of some expert provocative cytokines created by the unhealthy periodontal tissues that may be an essential fiery cytokine empowering corpulence.

Oral microscopic organisms may be added in the improvement of weight by no less than three components. Theory is that the oral microscopic organisms can expand weight pickups by expanding craving. Indeed, without information, teleology of the recommendation is smart to the point that it ought to be specified in unique situation. By empowering host hunger, microscopic organisms motivate to eat more.

Subsequently, any investigation of disease related weight pickups ought to incorporate an evaluation of exercise \& diet, 
which was not joined into our pilot contemplate. It should be perceived that an essential restriction of the examination as directed is the utilization of a comfort populace as a control, instead of utilizing chosen accomplices. While it isn't legitimized to propose that Selenomonas noxia diseases have an etiologic part in stoutness, in view of these information, it is sensible to recommend that Selenomonas noxia might be a pointer of progress in oral microbial environment Mager et al. [14].

The connection between the oral bacteria and obesity was certainly complex and diverse. The relationship might be fortuitous as being connected with food intake. It is also evidenced that multiple metabolic process and numerous other factors also have a positive correlation with obesity. Whatever the reason behind these microbial populations are diverse and may exist in obese and healthy individuals taking their part in human health and physiology [15-28].

\section{Conclusions}

The 5 bacterial phyla including, Firmicutes, Actinomyces, Bacterides, Spirochaetae were evaluated in the obese and healthy individuals. Presently detected bacterial species from the above mentioned five phyla were increasingly present in the obese individuals compared to non-obese. A positive correlation was observed in the oral microflora and obesity since some of the bacterial species were only detected in the obese median. The presence of specific bacterial population in the obese individuals and their absence in the healthy population is an indication of relationship among oral microflora and obesity. The further research studies are needed to develop the correlation of microbial population in the oral cavity and obesity. It is also expected that obese individual may be treated through exchange of microbial communities in their oral cavity.

\section{Acknowledgment}

We feel gratitude in acknowledging the United States Pakistan Center for Advanced Studies (USPCAS) department for provision of necessary facilities during the research work.

\section{References}

1. Bharmal FY, DS Akram, M Agboatwalla (2000) Community Growth Monitoring. JPMA 50(6): 159-167.

2. Burdette AM, Hill TD (2008) An examination of processes linking perceived neighborhood disorder and obesity. Soc Sci Med 67(1): 38-46.

3. Blustein J, Liu J (2015) Time to consider the risks of caesarean delivery for long term child health. BMJ 350: 213-215.

4. Yamanaka W, Takeshita T, Shibata Y (2012) Compositional Stability of a Salivary Bacterial Population against Supragingival Microbiota Shift following Periodontal Therapy. PLoS One 9: 67-93.

5. Kaplan JB (2010) Biofilm dispersal: mechanisms, clinical implications, and potential therapeutic uses. J Dent Res 39(3): 205-218.

6. Rasiah IA, Wong L, Anderson SA, Sissons CH (2005) Variation in bacterial DGGE patterns from human saliva: over time, between individuals and in corresponding dental plaque microcosms. Arch Oral Biol 50(9): 779-787.
7. Goodson JM, Groppo D, Halem S, Carpino E (2009) Is obesity an oral bacterial disease. Dent Res 38(6): 519-523.

8. Yoshizawa JM, Schafer CA, Schafer JJ (2013) Salivary biomarkers: toward future clinical and diagnostic utilities. Clin Microbiol Rev 26(4): 781-791.

9. Ley RE, Turnbaugh PJ, Klein S, Gordon JI (2006) Microbial ecology: human gut microbes associated with obesity. Nature 444(7122): 10221023.

10. Reinhardt C, Reigstad CS, Backhed F (2009) Intestinal microbiota during infancy and its implications for obesity. J Pediatr Gastroenterol Nature 48(3): 249-256.

11. Turnbaugh PJ, Hamady M, Yatsunenko T, Cantarel BL, Duncan A, et al. (2009) A core guts microbiome in obese and lean twins. Nature 457(7228): 480-484.

12. Elli M, Colombo O, Tagliabue A (2010) A common core microbiota between obese individuals and their lean relatives? Evaluation of the predisposition to obesity on the basis of the fecal microflora profile. Med Hypotheses 75(4): 350-352.

13. Socransky SS, Haffajee AD (2005) Periodontal microbial ecology. Periodontol 2000 38: 135-187.

14. Mager DL, Ximenez-Fyvie LA, Haffajee AD, Socransky SS (2003) Distribution of selected bacterial species on intraoral surfaces. J Clin Periodontol 30: 644-654.

15. Buduneli N, Baylas H, Buduneli E, Türkoğlu O, Köse T, et al. (2005) Periodontal infections and pre-term low birth weight: a case-control study. J Clin Periodontal 32(2): 174-181.

16. Cani PD, Delzenne NM (2007) Gut microflora as a target for energy and metabolic homeostasis. Curr Opin Clin Nutr Metab Care 10(6): 729734.

17. Christakis NA, Fowler JH (2007) The spread of obesity in a large social network over 32 years. N Engl J Med 357(4): 370-379.

18. DiBaise JK, Zhang H, Crowell MD, Krajmalnik-Brown R, Decker GA, et al. (2008) Gut microbiota and its possible relationship with obesity. Mayo Clin Proc 83(4): 460-469.

19. Euzeby JP (2008) List of prokaryotic names with standing in nomenclature: a folder available on the Internet. Classifications of domains and phyla, pp. 590-592.

20. Iwamoto $Y$, Nishimura F, Nakagawa M, Sugimoto H, Shikata K, et al. (2001) The effect of antimicrobial periodontal treatment on circulating tumor necrosis factor-alpha and glycated hemoglobin level in patients with type 2 diabetes. J Periodontol 72(6): 774-778.

21. Janket SJ, Wightman A, Baird AE, Van Dyke TE, Jones JA (2005) Does periodontal treatment improve glycemic control in diabetic patients? A meta-analysis of intervention studies. J Dent Res 84(12): 1154-1159.

22. Lundin M, Yucel-Lindberg T, Dahllof G, Marcus C, Modéer T (2004) Correlation between TNF alpha in gingival crevicular fluid and body mass index in obese subjects. Acta Odontol Scand 62(5): 273-277.

23. Moore WE, Holdeman LV, Smibert RM, Cato EP, Burmeister JA, et al. (1984) Bacteriology of experimental gingivitis in children. Infect Immun 46(1): 1-6.

24. Ritchie CS (2007) Obesity and periodontal disease. Periodontol 2000 14(2): 154-163.

25. Sekirov I, Russell SL, Antunes LC (2010) Gut microbiota in health and disease. Physiol Rev 90: 859-904.

26. Socransky SS, Haffajee AD (2005) Periodontal microbial ecology. Periodontol 38: 135-187.

27. Tanner A, Maiden MF, Macuch PJ, Murray LL, Kent RL Jr, et al. (1998) 


\section{Current Research in Diabetes \& Obesity Journal}

Microbiota of health, gingivitis, and initial periodontitis. J Clin Periodontol 25(2): 85-98.

28. Wood N, Johnson RB, Streckfus CF (2003) Comparison of body com- position and periodontal disease using nutritional assessment techniques: Third National Health and Nutrition Examination Survey (NHANES III). J Clin Periodontol 30(4): 321-327.

Your next submission with Juniper Publishers
will reach you the below assets
- Quality Editorial service
- Swift Peer Review
- Reprints availability
- E-prints Service
- Manuscript Podcast for convenient understanding
- Global attainment for your research
- Manuscript accessibility in different formats
( Pdf, E-pub, Full Text, Audio)
- Unceasing customer service
Track the below URL for one-step submission
https://juniperpublishers.com/online-submission.php

